\title{
Meningkatkan Kognitif Siswa SMAN I Jambi Melalui Modul Berbasis E-Book Kvisoft Flipbook Maker
}

\author{
Mulyadi Rusli, Louis Antonius \\ Prodi Sistem Informasi STMIK Nurdin Hamzah, Jambi, Indonesia \\ Email: mulyadiroesly@gmail.com, Louis@ stmiknh.ac.id
}

\begin{abstract}
Abstrak-Penelitian ini untuk menghasilkan modul berbasis e- book menggunakan aplikasi Kvisoft Flipbook Maker yang layak guna meningkatkan kognitif siswa dan mengetahui peningkatan minat belajar siswa SMA dengan menggunakan media pembelajaran modul berbasis e-book aplikasi Kvisoft Flipbook Maker, dan mengetahui peningkatan kognitif siswa dalam menggunakan media pembelajaran modul berbasis e-book menerapkan aplikasi Kvisoft Flipbook Maker.Hasil penelitian menunjukkan bahwa: modul berbasis e-book menggunakan aplikasi ini layak digunakan untuk meningkatkan minat dan hasil belajar kognitif siswa SMA ditinjau dari penilaian praktisi dengan kategori sangat baik dan dari hasil respon siswa dengan kategori baik, peningkatan minat belajar siswa yang menggunakan modul berbasis e-book menggunakan aplikasi Kvisoft Flipbook Maker dengan skor standar gain dalam kategori rendah, dan peningkatan hasil belajar kognitif siswa yang menggunakan modul berbasis e-book menggunakan aplikasi Kvisoft Flipbook Maker dengan skor standar gain dalam kategori sedang.
\end{abstract}

Kata Kunci: e-book, Kvisoft Flipbook Maker, hasil belajar kognitif

\begin{abstract}
Abstrack-This research was aimed to: produce module based on e-book using Kvisoft Flipbook Maker application that proper to increase learning interest and cognitive learning outcome, know the increasing interest of senior high school students which use learning media module based on e-book using Kvisoft Flipbook Maker application, and know the increasing of cognitive learning outcome of senior high school students which use learning media module based on e-book using Kvisoft Flipbook Maker application. The result show that: the module based on e-book using Kvisoft Flipbook Maker application is proper to increase learning interest and cognitive learning outcome of senior high school students seen from very good and good results category of practitioner appraisal and student's response, the increasing of student's learning interest which use module based on e-book using Kvisoft Flipbook Maker application by low category standard gain, and the increasing of student's cognitive learning outcome which use module based on e-book using Kvisoft Flipbook Maker application by medium category standard gain.
\end{abstract}

Keywords: e-book, Kvisoft Flipbook Maker, learning interest, cognitive learning

\section{PENDAHULUAN}

Fisika dalam Permendikbud Nomor 59 tahun 2014 merupakan bagian dari Ilmu Pengetahuan Alam (IPA) yang merupakan usaha sistematis dalam rangka membangun dan mengorganisasikan pengetahuan dalam bentuk penjelasan-penjelasan yang dapat diuji dan mampu memprediksi gejala alam. Pada praktik pembelajaran fisika peserta didik dapat memperoleh pengalaman langsung dan dapat menambah kekuatan untuk menerima, menyimpan, dan menerapkan konsep yang telah dipelajarinya dalam kehidupan sehari-hari. Pernyataan tersebut juga sejalan dengan pernyataan [1], fisika dalam mengkaji objek-objek telaahnya yang berupa benda-benda serta peristiwa-peristiwa alam menggunakan prosedur baku yang biasa disebut metode atau proses ilmiah. Oleh karena itu, proses pembelajaran dan penilaian hasil belajar fisika seharusnya dapat mencerminkan karakteristik keilmuan tersebut.

Pendidikan sendiri mempunyai tujuan untuk mengembangkan potensi peserta didik agar menjadi manusia yang beriman dan bertakwa kepada Tuhan Yang Maha Esa, berakhlak mulia, sehat, berilmu, cakap, kreatif, mandiri, dan menjadi warga negara yang demokratis serta bertanggung jawab (Undang-Undang Nomor 20 Tahun 2003 tentang Sistem Pendidikan Nasional). Upaya yang dapat dilakukan guna mencapai tujuan pendidikan itu dapat ditempuh melalui proses pendidikan yang baik dan terencana. Proses pendidikan menurut Permedikbud Nomor 59 tahun 2014 yaitu suatu proses yang memberikan kesempatan kepada peserta didik untuk mengembangkan potensi diri menjadi kemampuan berpikir rasional dan kecemerlangan akademik dengan cara memberikan makna terhadap apa yang dilihat, didengar, dibaca, dan dipelajari untuk diaplikasikan dalam kehidupan sehari-hari. Namun dalam praktiknya, proses pendidikan masih sangat sedikit memberikan kesempatan bagi peserta didik untuk mengembangkan potensi dirinya.

Untuk mengembangkan potensi diri peserta didik, maka peserta didik diharuskan aktif dalam proses belajar. Keaktifan tersebut dapat dicapai dengan penggunaan bahan ajar yang inovatif, variatif, menarik, kontekstual, dan sesuai dengan tingkat kebutuhan peserta didik. Dengan digunakannya bahan ajar yang demikian, maka diharapkan proses pembelajaran yang menyenangkan dapat tercipta, sehingga dapat memicu terjadinya proses pembelajaran yang efektif. Oleh karena itu, bahan ajar yang mampu membuat proses pembelajaran yang menyenangkan perlu diadakan. Salah satunya adalah modul berbasis $e$-book yang dikemas dengan menarik.

Modul berbasis e-book diharapkan dapat menambah keaktifan belajar siswa dengan syarat dikemas dengan menarik dan inovatif. Salah satunya adalah dengan tidak hanya memindah teks (hardcopy) dari media cetak ke media digital (softcopy) tetapi juga memuat gambar-gambar yang menjelaskan fenomena fisika yang dipelajari 
dan video karena video memuat gambar dan juga suara yang dapat menstimulasi indera penglihatan dan pendengaran siswa sehingga dapat memudahkan proses belajar.

Modul adalah satuan program pembelajaran terkecil yang dapat dipelajari oleh siswa secara perseorangan [2]. Modul tersebut memuat deskripsi tentang tujuan pembelajaran, lembaran petunjuk pengajar yang menjelaskan cara mengajar yang efisien, bahan bacaan bagi siswa, lembar kunci jawaban pada lembar kerja siswa, dan alat-alat evaluasi pembelajaran. Dengan menggunakan modul, siswa dapat mengukur sendiri tingkat penguasaan mereka terhadap materi yang dibahas pada setiap satu satuan modul.

Salah satunya adalah dengan mengembangkan media belajar modul berbasis e-book yang dikemas dengan kreatif dan inovatif. Dengan dikembangkannya modul berbasis e-book tersebut siswa akan lebih aktif dalam belajar dengan harapan akan meningkatkan minat belajar dan hasil belajar kognitif siswa dalam mata pelajaran fisika [3].

Tujuan Penelitian menghasilkan modul berbasis e-book menggunakan aplikasi Kvisoft Flipbook Maker yang layak guna meningkatkan minat belajar dan hasil belajar kognitif dan mengetahui peningkatan hasil belajar kognitif siswa yang menggunakan media pembelajaran modul berbasis e-book menggunakan aplikasi Kvisoft Flipbook Maker. Manfaat penelitian membantu guru dan calon guru untuk alternatif referensi belajar yang inovatif dan interaktif, sehingga dapat menumbuhkan minat kepada guru atau calon guru untuk membuat alternatif sumber belajar yang lebih baik.

\section{METODE PENELITIAN}

\subsection{Media Pembelajaran Fisika}

Media berasal dari bahasa Latin "medius" yang secara harfiah berarti tengah, perantara atau pengantar. Secara lebih khusus, pengertian media dalam proses pembelajaran cenderung diartikan sebagai alat-alat grafis, fotografis atau elektronis untuk menangkap, memproses, dan menyusun kembali informasi visual atau verbal. Media merupakan sesuatu yang bertindak sebagai alat untuk melaksanakan komunikasi. Dalam interaksi belajar mengajar, selanjutnya media dapat merupakan manusia, benda ataupun peristiwa yang membuat kondisi tertentu bagi peserta didik sehingga memungkinkan untuk memperoleh pengetahuan, keterampilan maupun sikap tertentu [4].

\subsection{Modul Elektronik}

Dalam Oxford Kamus bahasa Inggris, e-book adalah versi elektronik dari buku cetak yang dapat dibaca pada komputer pribadi atau perangkat genggam yang dirancang khusus untuk tujuan ini . E-book didedikasikan bagi para pembaca media elektronik atau perangkat $e$-book baik melalui komputer atau bisa juga melalui ponsel yang dapat digunakan untuk membaca buku elekronik ini. Dengan hadirnya e-book ini para pembaca dimudahkan untuk tidak menyimpan buku-buku favoritnya dalam bentuk fisik (buku konvensional) dan juga memudahkan bagi para penulis dalam menyebarkan tulisan-tulisannya, karena melalui $e$ book ini seseorang tidak perlu datang ke penerbit hanya sekedar menginginkan tulisannya dapat diterbitkan.

File-file yang sering digunakan untuk pengemasan dokumen tersebut sehingga bisa disebut $e$-book biasanya dalam format $p d f$, exe, doc, ppt, dan sebagainya. Yang lazim adalah $p d f$ dan exe. Akan tetapi tidak semua file dokumen yang berekstensi $p d f$ atau exe disebut $e$-book. Seperti halnya banyak dokumen kertas yang tidak serta merta bisa disebut buku, ada yang disebut selebaran, brosur, pamflet, modul, dan lain-lain. Maka file dokumen agar bisa disebut $e$-book tentunya harus memenuhi kaidah-kaidah penulisan buku dan tersusun dalam bentuk buku hanya saja tidak diwujudkan secara fisik (di-print) [5].

\subsection{Aplikasi Kvisoft Flipbook Maker}

Aplikasi Kvisoft Flipbook Maker adalah aplikasi yang dikenal sebagai perangkat lunak profesional pengubah pdf menjadi buku flash bolak-balik selama beberapa tahun. Perangkat lunak ini bias membuat buku bolakbalik HTML5 dan flash dari semua jenis file: pdf, gambar, Word, PowerPoint, Excel, dan lain-lain. Aplikasi ini dapat memperkaya buku digital, brosur, katalog, majalah, dan lain-lain menggunakan animasi bolakbalik halaman flash yang mengagumkan.

Buku bolak-balik 3D realistik ini dapat disajikan dalam berbagai perangkat seperti pada perangkat komputer, Mac, iPhone, iPad, iPod, Android, dan perangkat mobile lainnya yang mencakup audiens perangkat komputer dan mobile. Aplikasi ini dapat digolongkan sebagai mobile learning atau pembelajaran yang fleksibel terhadap waktu dan tempat. [6]. Mmobile learning adalah salah satu jenis media pembelajaran yang mudah dibawa kemana-mana dan dapat digunakan sesuai keinginan pengguna asalkan ada gadget yang memadai.

Kvisoft Flipbook Maker mempunyai halaman fungsi pengeditan yang memungkinkan untuk menambahkan video, gambar, audio, hyperlink, dan objek multimedia lebih ke output membolak- balikan halaman, membuat halaman multimedia membalik buku membuat begitu mudah dengan software ini. Kvisoft Flipbook Maker menyediakan sebuah cara profesional untuk mengintegrasikan hyperlink, video, gambar, suara, 
dan lebih multimedia clipcart objek untuk buku keluaran membalik halaman. Sebuah program untuk membuat publications digital. Aplikasi multimedia ini mempunyai interface (antar muka) seperti sebuah buku yang dibuka.

\subsection{Hasil Belajar Kognitif}

Hasil belajar dapat dijelaskan dengan memahami dua kata yang membentuknya yaitu "hasil" dan "belajar". Hasil menunjuk pada suatu perolehan yang didapatkan karena ada suatu proses. [7] Menurut pandangan kontruktivistik, belajar merupakan suatu proses pembentukan pengetahuan. Jadi dari teori diatas dapat disimpulkan bahwa hasil belajar merupakan hasil dari suatu proses pembelajaran dalam membentuk suatu pengetahuan.

\subsection{Prosedur Penelitian}

Penelitian ini menggunakan metode penelitian Research and Development (R\&D) dengan model pengembangan 4 D [8]. Model pengembangan 4 D (4D Models) terdiri atas 4 tahap utama yaitu: (1) Define (pendefinisian); (2) Design (perancangan); (3) Develop (pengembangan); (4) Desseminate (penyebarluasan). Penelitian ini dimaksudkan untuk mengembangkan modul dalam bentuk e-book sebagai media pembelajaran untuk meningkatkan minat dan hasil belajar kognitif fisika siswa SMA.

\subsection{Instrumen Penelitian}

\subsubsection{Perangkat Pembelajaran}

Dalam penelitian ini menggunakan Modul Berbasis E-book, Modul berbasis e-book adalah modul yang dikemas seperti e-book yang dilengkapi materi, media audio-visual, dan evaluasi dan Rencana Pelaksanaan Pembelajaran (RPP) digunakan sebagai pedoman pendidik dalam melaksanakan kegiatan pembelajaran di kelas agar materi yang disampaikan dapat sistematis dan sesuai dengan tujuan pembelajaran yang telah ditetapkan [8].

2.6.2 Instrumen Pengumpul Data

Instrumen pengumpul data yang digunakan dalam penelitian ini adalah :

a. Angket validasi Instrumen ini untuk memperoleh data tentang penilaian dari praktisi terhadap media yang dikembangkan. Hasil dari penilaian ini dijadikan dasar untuk memperbaiki media modul berbasis e-book sebelum diujicobakan. Aspek penilaiannya meliputi aspek kelengkapan materi, kegiatan yang mendukung materi, kemuktahiran materi, materi dapat meningkatkan kompetensi sains siswa, materi merangsang siswa untuk mencari tahu, penyajian mempertimbangkan kebermaknaan dan kebermanfaatan, melibatkan siswa secara aktif, tampilan umum, anatomi modul fisika, kemudahan dipahami, ketepatan menggunakan bahasa, kejelasan menggunakan bahasa, penampilan gambar, penampilan modul, dan cover modul.

b. Soal-soal Pretest dan Posttest Instrumen pretest digunakan untuk mengetahui penguasaan materi awal peserta didik sebelum mengikuti pembelajaran menggunakan media pembelajaran modul berbasis e-book, sedangkan instrumen posttest digunakan untuk mengetahui penguasaan materi siswa setelah mengikuti pembelajaran menggunakan media modul berbasis e-book.

c. Angket Respon Siswa terhadap Media Instrumen ini digunakan untuk mengetahui tanggapan atau respon siswa terhadap penggunaan media modul berbasis e-book yang dikembangkan pada pembelajaran materi pokok Usaha dan Energi. Pernyataan dalam angket mewakili lima aspek: 1) materi pembelajaran dalam modul, 2) cara penyajian dalam modul, 3) keterbacaan bahasa dan gambar, 4) tampilan fisik, dan 5) penggunaan modul. Adapun kisi-kisi angket respon siswa terhadap modul elektronik berbasis fisika

d. Angket Minat Belajar Fisika Siswa Instrumen ini digunakan untuk mengetahui seberapa besar pencapaian minat siswa terhadap kegiatan pembelajaran fisika menggunakan modul berbasis e-book. Selain itu, angket minat belajar dikembangkan untuk mengukur minat belajar siswa ketika sebelum mengikuti pembelajaran dan sesudah pembelajaran. Angket minat belajar hanya diberikan pada kelas eksperimen. Kisi-kisi angket minat belajar siswa disajikan pada Tabel 1. Kualitas angket minat belajar dinyatakan dari proses validasi internal dengan teknik perhitungan Aiken's V yang selengkapnya dijelaskan pada bagian Validitas dan Reliabilitas Instrumen [9].

Tabel 1. Kisi-kisi angket minat belajar siswa

\begin{tabular}{lllcc}
\hline No. & Indikator Minat & \multicolumn{2}{c}{$\begin{array}{c}\text { Sebaran Nomor Butir Pernyataan } \\
\text { Positif }\end{array}$} & $\begin{array}{c}\text { Negatif } \\
\text { Pernyataan }\end{array}$ \\
\hline 1 & Perasaan senang & $1,2,3,21$ & 9 & 5 \\
2 & Ketertarikan & $5,6,7,8,24$ & 17 & 6 \\
3 & Perhatian & $10,12,13,14,224$ & - & 6 \\
4 & Keterlibatan & $15,16,18,19,20,23$ & 11 & 7 \\
& & & Total Pernyataan & 24 \\
\hline
\end{tabular}

\subsection{Teknik Pengumpulan Data}

1. Melaksanakan pretest dan posttest untuk mengetahui prestasi belajar awal dan akhir siswa. 
2. Memberikan angket minat belajar fisika siswa untuk mengetahui seberapa besar pencapaian minat siswa terhadap kegiatan pembelajaran fisika menggunakan modul berbasis e-book.

3. Memberikan angket respon siswa untuk mengetahui tanggapan siswa terhadap media pembelajaran modul berbasis e-book yang dikembangkan.

\subsection{Teknik Analisis Data}

1. Data Kualitatif yang terdiri dari hasil validasi oleh praktisi, dan respon siswa yang berupa komentar atau saran dianalisis secara deskriptif kualitatif. Analisis data ini sebagai bahan revisi media yang dikembangkan.

2. Data Kuantitatif

a. Data Angket Validasi Produk, Penilaian dari praktisi berupa skor angket validasi media modul berbasis ebook dengan skala 1 sampai dengan 5, untuk setiap kriteria. Hasil penilaian tersebut dianalisis menggunakan SBI. Kelayakan modul dilihat dari dua aspek utama yaitu materi dan media. Tiap aspek dibagi menjadi beberapa sub-aspek dan tiap sub-aspek terdiri dari beberapa pernyataan. Penilaian dilakukan dari jumlah nilai perolehan tiap pernyataaan untuk setiap sub-aspek. Analisis data lembar penilaian menggunakan analisis deskriptif kuantitatif dengan langkah-langkah sebagai berikut:

1. Mencari skor rata-rata penilaian produk, menggunakan rumus:

$$
X=\underline{\Sigma} \mathrm{x}
$$

Dengan $X$ adalah skor rata-rata, $\mathrm{n}$ adalah jumlah butir, dan $\Sigma x$ adalah jumlah skor butir

2. Nilai rata-rata total skor masing-masing aspek yang diperoleh kemudian dikonversikan menjadi data kualitatif berupa tingkat kelayakan produk [10]. Pedoman konversinya sebagai berikut:

Tabel 2. Pedoman Kategori Penilaian Skala Lima

\begin{tabular}{llll}
\hline No Interval Skor & Nilai & Kategori \\
\hline 1 & $X>X \mathrm{i}+1,8 S \mathrm{Bi}$ & $\mathrm{A}$ & Sangat Baik \\
2 & $X i+0,6 \mathrm{Bi}<X \leq X \mathrm{i}+1,8 S \mathrm{Bi}$ & $\mathrm{B}$ & Baik \\
3 & $X i-0,6 \mathrm{Bi}<X \leq X \mathrm{i}+0,6 \mathrm{Bi}$ & $\mathrm{C}$ & Cukup \\
4 & $X i-1,8 S \mathrm{Bi} i<X \leq X \mathrm{i}-0,6 \mathrm{BBi}$ & $\mathrm{D}$ & Kurang \\
5 & $X \leq X \mathrm{i}-1,8 S \mathrm{Bi}$ & $\mathrm{E}$ & Sangat Kurang \\
\hline
\end{tabular}

Berdasarkan Tabel 2, dapat diperoleh pedoman pengkonversian nilai kuantitatif 1 sampai 5 menjadi kategori kualitatif untuk menyimpulkan bagaimana tingkat kelayakan media yang dikembangkan. Jika nilai $X i$ dan SBi disubsitusikan pada rumus yang ada di Tabel 3.

Tabel 3. Konversi Skor Aktual Menjadi Kategori Kualitatif

\begin{tabular}{llll}
\hline No Rentang Skor Kuantitatif & Nilai & Kategori \\
\hline 1 & $X>4,21$ & A & Sangat Baik \\
2 & $3,40<X \leq 4,21$ & B & Baik \\
3 & $2,30<X \leq 3,40$ & C & Cukup \\
4 & $1,79<X \leq 2,30$ & D & Kurang \\
5 & $X \leq 1,79$ & E & Sangat Kurang \\
\hline
\end{tabular}

2. Data Pretest dan Posttest Teknik pengumpulan data menggunakan tes pretest-posttest dilakukan untuk mengetahui hasil belajar siswa setelah menggunakan modul berbasis e-book menggunakan aplikasi Kvisoft Flipbook Maker. Tes ini dilakukan dengan memberikan pretest sebelum menggunakan modul modul berbasis e-book menggunakan aplikasi Kvisoft Flipbook Maker dan posttest setelah siswa menggunakan modul modul berbasis e-book menggunakan aplikasi Kvisoft Flipbook Maker. Apakah terdapat peningkatan penguasaan materi siswa berdasarkan nilai pretest dan posttest siswa, baik pada uji coba terbatas maupun uji coba lapangan. Peningkatan ini dinyatakan dengan nilai standard gain. Standard gain dapat dicari dengan menggunakan rumus [11]:

$$
\text { standar gain }=\frac{\bar{X} \text { posttest }-\overline{\mathrm{X}} \text { pretest }}{100-\mathrm{X} \text { pretest! }}
$$

Tabel 4. Interpretasi Standard Gain

\begin{tabular}{ll}
\hline Nilai Standart Gain & Kriteria \\
\hline$(\mathrm{g}) \geq 0,7$ & Tinggi \\
$0,7>(\mathrm{g}) \geq 0,3$ & Sedang \\
$(\mathrm{g})<0,3$ & Rendah \\
\hline
\end{tabular}

c. Data Angket Respon Siswa terhadap Media menggunakan analisis deskriptif dengan langkah-langkah sebagai berikut:

1. Mengubah skala pernyataan ke dalam nilai skala 1 sampai dengan 4 yaitu: $1=\mathrm{SS}:$ Sangat Setuju, $2=$ S : Setuju, $3=$ TS : Tidak Setuju dan $4=$ STS : Sangat Tidak Setuju 
2. Mencari skor rata-rata butir pernyataan respon siswa

3. Nilai rata-rata total skor masing-masing aspek yang diperoleh dikonversikan menjadidata kualitatif berupa kriteria kelayakan produk [12].

Tabel 5. Konversi Skor Menjadi Skala 4

\begin{tabular}{lll}
\hline No. & Rentang Skor Kuantitatif & Kategori Kualitatif \\
\hline 1 & $X \geq(X+1 . S \mathrm{Bi})$ & Sangat Baik/Sangat Tinggi \\
2 & $(X i+1 . S \mathrm{Bi}) \geq X \geq X$ & Baik/Tinggi \\
3 & $X i \geq X \geq(X i-1 . S \mathrm{Bi})$ & Kurang Baik/Rendah \\
4 & $X \leq(X i-1 . S \mathrm{Bi})$ & Sangat Kurang Baik/Sangat Rendah \\
\hline
\end{tabular}

a) Mencari rata-rata ideal $\left(\begin{array}{ll}X & 1\end{array}\right)$ menggunakan rumus :

$X 1=1 / 2$ (skore mak ideal + skore min ideal)

Berdasarkan Tabel 5, dapat diperoleh pedoman pengkonversian nilai kuantitatif 1 sampai 4 menjadi kategori kualitatif untuk menyimpulkan bagaimana tingkat kelayakan media yang dikembangkan. Jika nilai $X i$ dan $\mathrm{SB} i$ akan diperoleh pedoman konversi seperti disajikan pada Tabel 6.

Tabel 6. Pedoman Konversi Skor

\begin{tabular}{lll}
\hline No Rentang Skor Kuantitatif & Kategori Kualitatif \\
\hline 1 & $X>3$ & Sangat Baik / Tinggi \\
2 & $3 \geq X>2,5$ & Baik / Sedang \\
3 & $2,5 \geq X>2$ & Kurang Baik / Rendah \\
4 & $X \leq 2$ & Sangat Kurang Baik / Kurang \\
\hline
\end{tabular}

b. Data Angket Minat Belajar Fisika Siswa

Analisis data angket pada minat belajar siswa menggunakan analisis deskriptif yang sama seperti dengan analisis data angket respon siswa. Adapun pedoman pengkonversian nilai kuantitatif 1 sampai 4 menjadi kategori kualitatif untuk menyimpulkan bagaimana tingkat penumbuhan minat belajar dengan menggunakan media modul berbasis e-book adalah menggunakan pedoman konversi.

\subsection{Validitas dan Reliabilitas Instrumen}

Kelayakan instrumen sebagai alat pengumpul data dapat dilihat dari kriteria valid dan reliabel instrumen tersebut. [11]. Bahwa reliabilitas adalah sejauh mana hasil suatu pengukuran dapat dipercaya, sedangkan validitas adalah sejauh mana akurasi suatu tes atau skala dalam menjalankan fungsi pengukurannya. [12] Menggolongkan validitas menjadi dua jenis, yaitu validitas internal dan eksternal. Validitas internal atau validitas logis adalah tingkat kevalidan instrumen yang diperoleh dari penalaran atau rasional yang didasarkan dari kriteria di dalam instrumen tersebut, sedangkan validitas eksternal adalah validitas yang didasarkan dari kriteria di luar instrumen yang dieproleh dari data empiris atau fakta.

Dalam penelitian ini, penelusuran validitas dan reliabilitas hanya dilakukan pada: (1) angket minat belajar siswa, (2) soal pretest-posttest, dan (3) angket respon siswa terhadap modul berbasis e-book menggunakan aplikasi Kvisoft Flipbook Maker. Adapun penelusuran validitas dan reliabilitas instrumen ditelusuri dengan teknik berikut 1. Koefisien validitas Aiken (Aiken's V)

Koefisien validitas Aiken termasuk dalam teknik validasi internal karena hanya menilai validitas isi/konten dari butir tes. [13] Menyatakan bahwa untuk menghitung koefisien validitas isi (content- validity coefficient) butir perangkat tes yang dinilai oleh praktisi sebanyak $\mathrm{n}$ dapat dilakukan dengan persamaan berikut:

$$
\mathrm{V}=\frac{\sum \mathrm{s}}{\mathrm{-a}(\mathrm{c}-1)}
$$

dengan criteria $\mathrm{s}=\mathrm{r}-1_{0:} \mathrm{l}_{0}$ : Angka penilaian validitas yang terendah:

c : Angka penilaian validitas yang tertinggi:

$\mathrm{r}$ : Angka yang diberikan penilai:

$\mathrm{n}$ : Banyaknya penilai

Penentuan validitas tersebut dipandang dari segi sejauh mana butir (item) mewakili konstrak yang diukur. Skor hasil perhitungan validitas Aiken berkisar antara 0-1, semakin besar atau semakin skor mendekati 1 maka semakin baik validitasnya. Persamaan Aiken's V tersebut digunakan untuk menentukan validitas isi dari beberapa instrumen.

2. Koefisien Alpha Cronbach $(\alpha)$

Estimasi reliabilitas instrumen dapat dilakukan salah satunya melalui teori tes klasik (classical test theory) dengan pendekatan konsistensi internal (internal consistency). Formula alpha digunakan untuk mengestimasi koefisien reliabilitas dari soal tes. pendekatan konsistensi internal data skor diperoleh melalui prosedur satu 
kali pengenaan satu tes kepada sekelompok individu sebagai subjek (single-trial administration), sehingga metode ini mempunyai nilai praktis dan efisiensi yang tinggi disbanding prosedur tes-ulang dan bentuk-paralel. Oleh karena itu, soal tes yang telah dilakukan validasi isi kemudian dilakukan uji coba empiris kepada siswa. Adapun formula koefisien alpha yang dikutip dari [14]. Cronbach untuk estimasi terhadap reliabilitas skor tes yang dibelah menjadi dua bagian adalah sebagai berikut.

$$
\text { r_xx } 1 \geq \alpha=2\left[1-\left(\left(s^{\wedge} 2 \quad y 1+s^{\wedge} 2 \quad y 2\right)\right) /\left(s^{\wedge} 2 x\right)\right]
$$

Untuk menghitung reliabilitas tes berbentuk uraian dapat dilakukan dengan persamaan berikut.

$$
r 11=-----\left(1-\sum \operatorname{si} 2 n i-1 \text { st } 2\right)
$$

dengan criteria ; $r x x^{\prime}$ dan $r 11=$ koefisien reliabilitas :

$$
\begin{aligned}
& \text { sx } 2 \text { = varians skor tes : } \\
& \text { sy1 } 2 \quad \text { = varians skor belahan } 1: \\
& \text { sy2 } 2 \text { varians skor belahan } 2: \\
& \text { si2 } 2 \text { varians skor soal ke-I : } \\
& \text { st } 2=\text { varians skor total : } \\
& n \quad=\text { banyak butir soal }
\end{aligned}
$$

Selain dapat dihitung dengan dua persamaan di atas, estimasi koefisien reliabilitas dapat dilakukan dengan bantuan software SPSS (Statistical Program for Social Science). SPSS memproses koefisien alpha dari data distribusi skor butir tanpa membelah atau membagi aitem menjadi kelompok-kelompok sehingga jumlah butir tidak menjadi hambatan menghitung koefisien alpha. Adapun langkah-langkah menganalisis dengan SPSS. a. Menuliskan data pada tab data file, b. Setelah data file diaktifkan, klik menu Analyze, pilih Scale, pilih submenu Reliability Analysis, c. Pada kotak dialog Reliability Analysis yang muncul, pindahkan semua butir item dari kotak kiri ke dalam kotak sebelah kanan, lalu pilih tombol Statistics. Dan d. Setelah kotak dialog Statistics terbuka, tandai atau klik kotak F-test, kemudian klik Continue. Setelah kembali ke kotak dialog Reliability Analysis, klik OK. Akan muncul hasil analisis pada jendela Output [15].

\section{ANALISA DAN PEMBAHASAN}

Hasil penelitian disajikan secara runtut sesuai dengan urutan pertanyaan penelitian. Hasil penelitian dideskripsikan melewati tiga tahapan yang juga merupakan bagian dari tahapan desain penelitian yaitu: (a) perancangan awal, (b) penilaian dan/atau validasi, dan (c) pengujian pengembangan. Kelayakan modul elektronik berbasis Kvisoft Flipbook Maker

Perancangan awal modul elektronik berbasis Kvisoft Flipbook Maker disusun dengan membuat format awal. disajikan pada Tabel 7 berikut.

Tabel 7. Desain Awal Modul Berbasis E-book Aplikasi Kvisoft Flipbook Maker

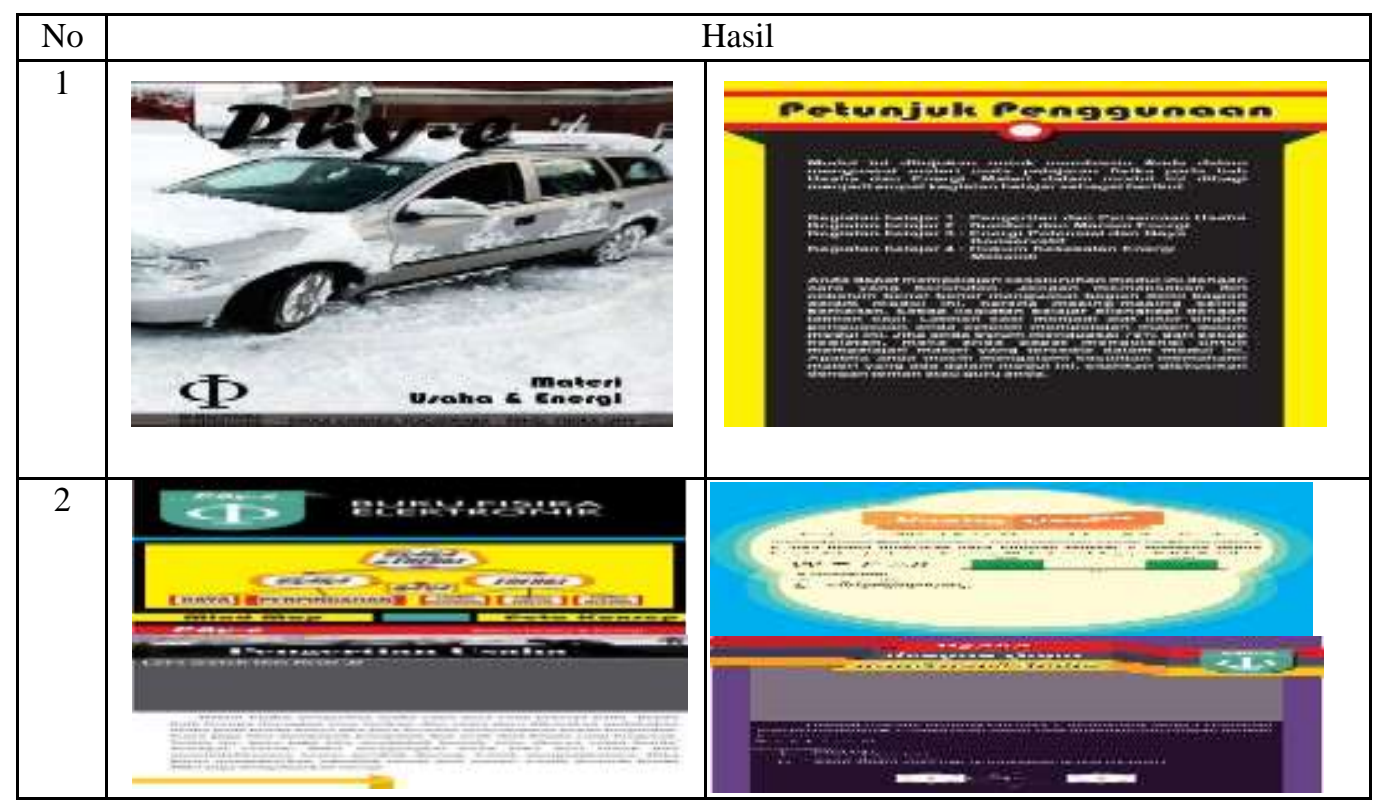

Di dalam modul elektronik fisika berbasis aplikasi Kvisoft Flipbook Maker tersebut disematkan empat video sebagai penarik minat siswa. Tampilan 2 (dua) video pada modul elektronik fisika berbasis aplikasi Kvisoft Flipbook Maker ditunjukkan dalam Tabel 8. 
Tabel 8. Video pada Modul Berbasis E-book Aplikasi Kvisoft Flipbook Maker

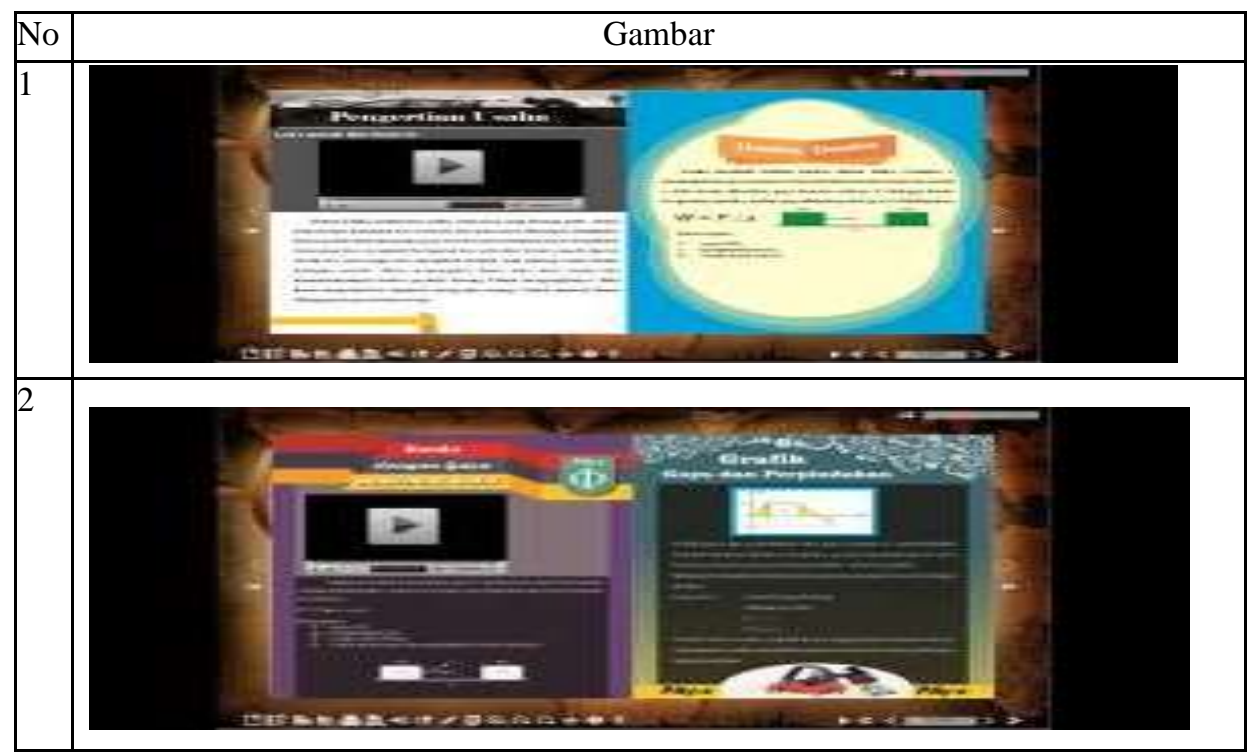

Untuk mengintegrasikan penggunaan modul elektronik fisika berbasis aplikasi Kvisoft Flipbook Maker dalam kegiatan pembelajaran, maka disusunlah RPP dengan kegiatan pembelajaran yang menggunakan modul elektronik fisika berbasis aplikasi Kvisoft Flipbook Maker

\subsection{Validasi}

Modul elektronik fisika berbasis aplikasi Kvisoft Flipbook Maker dan RPP yang telah disusun dan Sebelum digunakan untuk menjaring data respon siswa divalidasi (isi/content) oleh dua orang praktisi.

Tabel 9. Hasil Penilaian RPP

\begin{tabular}{rl|c|c|}
\hline No & \multicolumn{1}{|c|}{ Aspek } & $X$ & Kategori \\
\hline 1 & Identitas Mata Pelajaran & 5.00 & Sangat Baik \\
2 & Perumusan Indikator & 5.00 & Sangat Baik \\
3 & Perumusan Tujuan Pembelajaran & 5.00 & Sangat Baik \\
4 & Pemilihan Materi Ajar & 4.50 & Sangat Baik \\
5 & Pemilihan Sumber Belajar & 4.25 & Sangat Baik \\
6 & Pemilihan Media Belajar & 4.25 & Sangat Baik \\
7 & Metode Pembelajaran & 5.00 & Sangat Baik \\
8 & Skenario Pembelajaran & 5.00 & Sangat Baik \\
9 & Penilaian & 5.00 & Sangat Baik \\
10 & Bahasa & 5.00 & Sangat Baik \\
& & 91.00 & Sangat Baik \\
\hline
\end{tabular}

Tabel 10. Hasil Validasi Angket Respon Peserta Didik Terhadap Modul Berbasis E-book Aplikasi Kvisoft Flipbook Maker

\begin{tabular}{llcc}
\hline No & \multicolumn{1}{c}{ Aspek Penilaian } & Aiken's V & Kategori \\
\hline 1 & Materi & 0.88 & Tinggi \\
2 & Penyajian & 0.88 & Tinggi \\
3 & Keterbacaan Bahasa dan Gambar & 0.88 & Tinggi \\
4 & Tampilan Fisik & 0.88 & Tinggi \\
5 & Penggunaan & 0.88 & Tinggi \\
& Rerata seluruh aspek & 0.88 & Tinggi \\
\hline
\end{tabular}

Selain dilakukan penilaian secara kuantitatif oleh praktisi, saran perbaikan juga diberikan untuk perbaikan modul elektronik fisika berbasis aplikasi Kvisoft Flipbook Maker yang dikembangkan. Adapun perbaikan dan revisi yang dilakukan tersaji pada Tabel 11 . 
Tabel 11. Revisi Modul Berbasis E-book Aplikasi Kvisoft Flipbook Maker

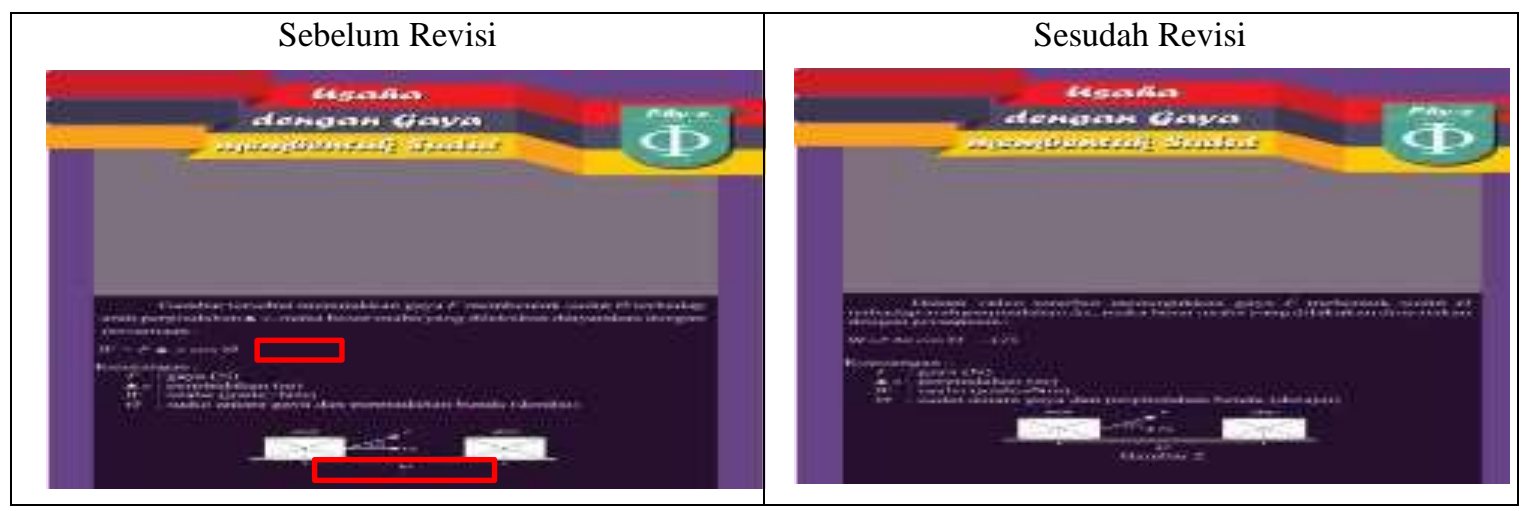

\subsection{Pengujian pengembangan}

1) Uji lapangan awal ; Pengujian pengembangan modul elektronik berbasis e-book menggunakan aplikasi Kvisoft Flipbook Maker pada uji lapangan awal tidak dilakukan, sehingga revisi pada media hanya dilakukan berdasarkan saran dari praktisi.

2) Uji lapangan utama dilakukan kepada 30 orang siswa kelas eksperimen dilakukan dengan cara memberikan modul elektronik fisika berbasis aplikasi Kvisoft Flipbook Maker kepada siswa kelas eksperimen dalam kegiatan pembelajaran dan mengumpulkan respon terhadap kepraktisan modul melalui angket respon peserta didik. Untuk mengetahui keterlaksanaan pembelajaran. Adapun hasil respon siswa pada uji lapangan utama yang dianalisis dengan SBI, sedangkan hasil secara singkat disajikan pada Tabel 12.

Tabel 12. Hasil Observasi Keterlaksanaan RPP

\begin{tabular}{ccccc}
\hline & \multicolumn{2}{c}{ Kelas Kontrol } & \multicolumn{2}{c}{ Kelas Eksperimen } \\
Pertemuan & Keterlaksanaan $(\%)$ & Keterangan & Keterlaksanaan $(\%)$ & Keterangan \\
\hline 1 & 70 & Kurang Baik & 83 & Baik \\
2 & 78 & Baik & 91 & Baik \\
3 & 74 & Baik & 83 & Baik \\
4 & 74 & Baik & 87 & Baik \\
Rata- rata $(\%)$ & 74 & & 86 & \\
\hline
\end{tabular}

Tabel 13. Hasil Respon Siswa Keefektifan E-book Aplikasi Kvisoft Flipbook Maker

\begin{tabular}{rlcc}
\hline No & \multicolumn{1}{c}{ Aspek } & $X$ & Kategori \\
\hline 1 & Materi & 2.833 & Baik \\
2 & Penyajian & 3.417 & Sangat Baik \\
3 & Keterbacaan Bahasa dan Gambar & 3.057 & Sangat Baik \\
4 & Tampilan Fisik & 3.104 & Sangat Baik \\
5 & Penggunaan & 3.174 & Sangat Baik \\
& Rerata Seluruh Aspek & 81.458 & Sangat Baik
\end{tabular}

Peningkatan minat belajar peserta didik SMA yang menggunakan media pembelajaran modul elektronik fisika berbasis aplikasi Kvisoft Flipbook Maker

a. Perancangan awal instrumen angket minat belajar siswa dari angket minat belajar sebelum pembelajaran dan sesudah pembelajaran.

b. Validasi

Hasil validasi angket minat belajar siswa, secara singkat disajikan pada gambar 1. 


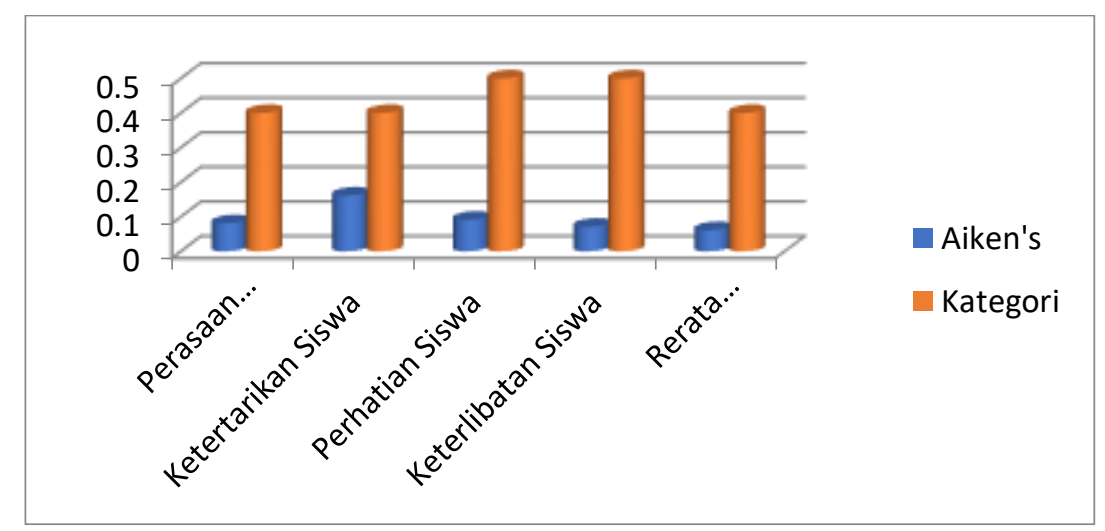

Gambar 1. Hasil Respon Siswa Keefektifan E-book Aplikasi Kvisoft Flipbook Maker

Kelayakan modul elektronik fisika berbasis aplikasi Kvisoft Flipbook Maker Kelayakan modul elektronik fisika berbasis aplikasi Kvisoft Flipbook Maker dapat diketahui dari hasil penilaian yang dilakukan praktisi dan respon siswa terhadap produk pembelajaran. a. Penilaian praktisi mengacu pada klasifikasi SBI. Secara keseluruhan, rerata besar penilaian yang diberikan adalah 284 dengan klasifikasi "Sangat Baik". Hasil tersebut dapat dipercaya mengingat penilaian dilakukan oleh dua orang dosen. Selain penilaian secara kuantitatif, praktisi juga memberikan saran perbaikan yang ditindaklanjuti dengan melakukan revisi untuk modul elektronik fisika berbasis aplikasi Kvisoft Flipbook Maker. b. Hasil angket respon siswa terhadap modul elektronik fisika berbasis aplikasi Kvisoft Flipbook Maker dilakukan validasi terlebih dahulu oleh praktisi. Hasil angket respon dianalisis menggunakan SBI. Hasil angket respon hanya didapat dari respon siswa pada uji lapangan utama. Hasil respon uji lapangan utama dengan kategori "Cukup". Penggunaan modul dalam pembelajaran juga dipengaruhi oleh RPP yang disusun. Selain penggunaan modul oleh siswa, modul juga ditampilkan pada layar LCD proyektor di depan kelas. Beberapa siswa merasa sangat antusias dengan penggunaan modul elektronik fisika berbasis aplikasi Kvisoft Flipbook Maker ini, sehingga memberikan saran untuk menerbitkan edisi selanjutnya dengan muatan materi yang berbeda. Seluruh pembahasan di atas merujuk pada kesimpulan bahwa modul elektronik fisika berbasis aplikasi Kvisoft Flipbook Maker dapat digunakan dengan baik dan layak pada kegiatan pembelajaran.

Peningkatan minat belajar peserta didik SMA yang menggunakan media pembelajaran modul elektronik fisika berbasis aplikasi Kvisoft Flipbook Maker. Dari segi peningkatan untuk setiap aspek minat (perasaan senang, ketertarikan, perhatian, dan keterlibatan) dan dari segi peningkatan minat umum setiap individu. Minat kelas eksperimen sebelum pembelajaran sudah dalam kategori sangat baik dan kategori minat setelah pembelajaran pun dalam kategori sangat baik dengan peningkatan signifikan dalam kategori gain rendah untuk kelas eksperimen. Peningkatan (gain) terjadi pada aspek ketertarikan dan perhatian siswa. Hal ini menunjukkan bahwa siswa merasa tertarik dengan pembelajaran yang dilakukan. Pada aspek perasaan senang dan keterlibatan tidak terjadi peningkatan, yang berarti penggunaan modul elektronik fisika berbasis aplikasi Kvisoft Flipbook Maker kurang mampu meningkatkan perasaan senang dan keterlibatan siswa.

Peningkatan minat belajar pada kelas eksperimen yang ditinjau dari hasil setiap individu menunjukkan hasil yang hampir sama seperti jika ditinjau dari setiap aspek minat. Gain yang diperoleh yang tergolong rendah, yang berarti meningkat secara tidak signifikan. Perubahan minat belajar siswa dari pretest ke posttest ditunjukkan melalui frekuensi kategori pada grafik tersebut. Pada grafik pretest frekuensi siswa dengan kategori minat "Sedang" sebanyak 5 orang menurun menjadi 2 orang pada grafik posttest, sedangkan siswa dengan kategori minat "Tinggi" dari 12 orang meningkat menjadi 13 orang, dan siswa dengan kategori minat "Sangat Tinggi" dari 17 orang meningkat menjadi 19 orang.

Jika ditinjau dari hasil yang diperoleh yaitu peningkatan minat belajar siswa kelas eksperimen tergolong rendah. Hal ini dapat dikarenakan dua hal yang terjadi ketika proses pengambilan data, yang pertama yaitu penempatan jam pelajaran Kegiatan Belajar Mengajar (KBM) fisika di SMAN 1 Kota Jambi rata-rata pada jam ke-6. Waktu KBM tersebut tentunya berpengaruh terhadap konsentrasi dan perhatian siswa selama proses pembelajaran.Kedua, adanya siswa mengisi angket dengan sikap yang kurang serius, hal ini ditunjukkan dengan adanya hasil angket minat belajar yang diisi dengan satu pilihan jawaban yang serupa secara keseluruhan. Selain itu, pada hasil respon siswa mengenai minat belajar sebelum dan sesudah menggunakan media sama-sama menunjukkan dalam kategori sangat baik. Dari penjelasan baik dari segi peningkatan setiap aspek minat maupun setiap individu, dapat disimpulkan bahwa modul elektronik fisika berbasis aplikasi Kvisoft Flipbook Maker dapat meningkatkan minat belajar siswa.

Peningkatan hasil belajar kognitif siswa SMA yang menggunakan media pembelajaran modul elektronik fisika berbasis aplikasi Kvisoft Flipbook Maker

Pengukuran hasil belajar kognitif siswa menggunakan perangkat soal tes pretest dan posttest. Sebelum dilakukan uji lapangan, soal tes dilakukan validasi isi oleh praktisi dimaknai sebagai butir yang memiliki validitas isi yang tinggi dan mendukung validitas isi seluruh tes. Setelah dilakukan validasi isi oleh praktisi, 
kemudian soal tes dilakukan uji empiris pada tahap uji lapangan awal. Hasil uji empiris kemudian dianalisis dengan SPSS untuk mencari tahu reliabilitas tes menggunakan teknik perhitungan Cronbach Alpha. Hasil analisis disajikan bahwa batas reliabilitas tes yang dapat diterima sehingga nilai reliabilitas tes yang dikembangkan dinyatakan dapat diterima.

\section{KESIMPULAN}

Berdasarkan seluruh proses penelitian pengembangan yang telah dilakukan sehingga dapat disimpulkan bahwa: Modul berbasis e-book menggunakan aplikasi Kvisoft Flipbook Maker layak digunakan untuk meningkatkan minat dan hasil belajar kognitif siswa berdasarkan hasil penilaian praktisi dengan kategori sangat baik dan dari hasil respon siswa dengan kategori baik. Peningkatan minat belajar siswa SMA yang menggunakan media pembelajaran modul berbasis e-book menggunakan aplikasi Kvisoft Flipbook Maker pada kelas eksperimen berdasarkan skor gain dengan kategori rendah. Peningkatan hasil belajar kognitif peserta didik SMA yang menggunakan media pembelajaran modul berbasis e-book menggunakan aplikasi Kvisoft Flipbook Maker pada kelas ekspeimen berdasarkan skor gain dengan kategori sedang

\section{REFERENCES}

[1] Mundilarto, (2010), Penilaian Hasil Belajar Fisika. Yogyakarta: Universitas Negeri Yogjakarta Press.

[2] Suprono, Andreas, (2012), Pengaruh Penggunaan Multimedia Interaktif terhadap Prestasi dan Minat Belajar Fisika di SMA Santa Maria Yogyakarta.

[3] Hake, Richard R, (2002), Relationship of individual student normalized gains in mechanics with gender, high-schoo physics, and pretest scores on mathematics and spatial visualization. Makalah disajikan dalam Physics Education Research Conference, Boise, Idaho.

[4] Ratnawulan, Elis dan Rusdiana, (2015), Evaluasi Pembelajaran. Bandung: Pustaka Setia

[5] Marthen Kanginan, (2017) Fisika untuk SMA/MA kelas X. Jakarta: Erlangga.

[6] Eko Suyanto \& Sartinem, (2009), Pengembangan Contoh Lembar Kerja Fisika Siswa dengan Latar Penuntasan Bekal Awal Ajar Tugas Studi Pustaka dan Keterampilan Proses untuk SMA Negeri 3 Bandar Lampung. Prosiding Seminar Nasional Pendidikan

[7] Paul Suparno, (2015), Metodologi Pembelajaran Fisika. Yogyakarta : Universitas Sanata Dharma.

[8] Arief S Sadiman, dkk, (2016), Konstruksi tes: Kemampuan Kognitif. Yogyakarta: Pustaka Pelajar

[9] Sugiyono, (2015), Metode Penelitian Pendidikan: Pendekatan Kuantitatif, Kualitatif, dan R\&D. Bandung: Alfabeta.

[10] Andi Prastowo, (2013), Panduan Kreatif Membuat Bahan Ajar Inovatif: Menciptakan Metode Pembelajaran yang Menarik dan Menyenangkan. Yogyakarta: Diva Press,

[11] Azwar, (2017), Reliabilitas dan validitas (Edisi 4). Yogyakarta: Pustaka Pelajar. Fisika FMIPA Universitas Negeri Yogjakarta kerjasama JICA.

[12] Aiken, Lewis R. (1980). Content validity and reliability of single items or questionnaires. Educational and Psychological Measurement.

[13] Serway, Raymond A \& Jewett, John W, Jr, (2010), Physics for Scientists and Engineers. Belmont: Brooks/Cole.

[14] Hamalik, Oemar. (2011). Kurikulum dan Pembelajaran. Jakarta: Sinar Grafika. Haryadi Sarjono \& Winda Juliaita, SPSS vs LISREL. Jakarta: Salemba Empat..

[15] Jamil Suprihatiningrum, Strategi Pembelajaran.DIY: Ar-ruzz Media. Kemendikbud. (2014). Permendikbud Nomor 59 Tahun 2014 Tentang Kurikulum 2013 Jakarta: Kemendikbud Juli 2016. 